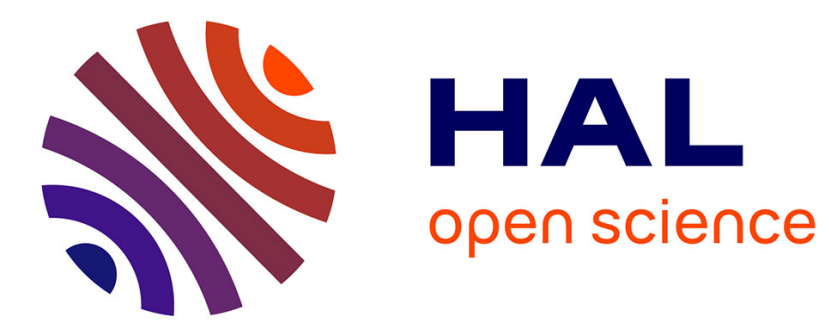

\title{
Delayed gametogenesis and spawning in rainbow trout (Salmo gairdneri) kept under permanent light during the first and second reproductive cycles
}

\author{
A. Bourlier, Roland Billard
}

\section{- To cite this version:}

A. Bourlier, Roland Billard. Delayed gametogenesis and spawning in rainbow trout (Salmo gairdneri) kept under permanent light during the first and second reproductive cycles. Aquaculture, 1984, 43 (1-3), pp.259-268. 10.1016/0044-8486(84)90027-9 . hal-01600567

\section{HAL Id: hal-01600567 \\ https://hal.science/hal-01600567}

Submitted on 2 Jun 2020

HAL is a multi-disciplinary open access archive for the deposit and dissemination of scientific research documents, whether they are published or not. The documents may come from teaching and research institutions in France or abroad, or from public or private research centers.
L'archive ouverte pluridisciplinaire $\mathbf{H A L}$, est destinée au dépôt et à la diffusion de documents scientifiques de niveau recherche, publiés ou non, émanant des établissements d'enseignement et de recherche français ou étrangers, des laboratoires publics ou privés.

\section{다(1)(2)}

Distributed under a Creative Commons Attribution - ShareAlikel 4.0 International 


\title{
DELAYED GAMETOGENESIS AND SPAWNING IN RAINBOW TROUT (SALMO GAIRDNERI) KEPT UNDER PERMANENT LIGHT DURING THE FIRST AND SECOND REPRODUCTIVE CYCLES
}

\author{
A. BOURLIER ${ }^{1}$ and R. BILLARD \\ Laboratoire de Physiologie des Poissons et Station de Physiologie Animale, I.N.R.A., \\ Campus de Beaulieu, F-35042 Rennes and 78350 Jouy en Jusas (France) \\ 'Present address: Les Salmonidés d'Aquitaine, Sarrance, 64490 Bedous, France.
}

\begin{abstract}
Bourlier, A. and Billard, R., 1984. Delayed gametogenesis and spawning in rainbow trout (Salmo gairdneri) kept under permanent light during the first and second reproductive cycles. Aquaculture, 43: 259-268.

Male and female rainbow trout in their first reproductive cycle were subjected to long days $(16 \mathrm{~L}: 8 \mathrm{D} ; 24 \mathrm{~L}: 0 \mathrm{D}$ and $16 \mathrm{~L}: 8 \mathrm{D}$ shifting progressively to $24 \mathrm{~L}: 0 \mathrm{D}$ within 6 months). All the fish were maintained at ambient temperatures of between 3 and $16^{\circ} \mathrm{C}$. Mean ovulation and spermiation times were 2 months later in the long-day group than in the control group, and ovulation and onset of spermiation were spread over a long period. The quantity and quality of the sexual products obtained were comparable in all groups. In subsequent experiments with the female groups, $50 \%$ of the females kept for the first time under permanent light ovulated or were about to ovulate $1-2$ months later than the controls. All females initially kept in LD during the first cycle also showed delayed ovulation but only a few ovulated. In the ovaries of ovulated and non-ovulated females, small vitellogenetic oocytes were found, indicating abnormalities in recruitment. Fish exposed for the first time to long days showed a delay in spawning but had normal ovulation.
\end{abstract}

\section{INTRODUCTION}

In commercial trout farms, it is useful to spread the availability of juveniles over the year in order to grow fish all year round to provide the market with a continuous production. There are several ways of expanding fry production outside the normal and very seasonal reproductive season: use of early or late-spawning strains, long-term embryo or gamete cryopreservation, hormone treatment, or changes in photoperiod. The aim of the present study was to investigate the possibility of delaying the spawning season in male and female rainbow trout by using long days or permanent light after the summer solstice. Such treatment has been successful in some salmonid species: brook trout (Allison, 1951; Hazard and Eddy, 1951; Henderson, 1963), and Pacific salmon and rainbow trout (Shiraishi and 
Fukuda, 1966; Bourlier and Billard, 1984). In the present experiment, males and females were subjected to long-day treatment during the first reproductive cycle and the photoperiodic regime was continued for a second year in the females since the oogenesis cycle lasts 2 years.

\section{MATERIAL AND METHODS}

The rainbow trout (Kaufman "strain"), bred under a natural environment in the experimental facilities of our laboratory at Jouy-en-Josas since hatching in January 1976, weighed between 800 and $900 \mathrm{~g}$ at the beginning of the experiment on 21 June 1977. During the first year the fish were divided into four groups of 60 each and placed in $2-\mathrm{m}^{3}$ fiberglass tanks:

group $\mathrm{C}$ : under a natural environment in the rearing facilities; temperature fluctuating between 3 and $16^{\circ} \mathrm{C}$; natural light and photoperiod;

group 16L: kept under a constant photoperiodic regime of $16 \mathrm{~L}: 8 \mathrm{D}$;

group $16 \mathrm{~L} \rightarrow 24 \mathrm{~L}$ : the increasing photoperiod was continued until it reached $24 \mathrm{~L}: 0 \mathrm{D}$ in January;

group $24 \mathrm{~L}_{1}$ : kept under constant light (24L : OD).

During the second year starting on 21 June 1978, these four groups were reorganized as follows: control group $\mathrm{C}$ was divided into two groups of 10 and 12 ; most were ovulated females; one group $\left(\mathrm{C}_{1}-\mathrm{C}_{2}\right)$ remained in the same natural fluctuating environment, and the other group $\left(\mathrm{C}_{1}-24 \mathrm{~L}_{2}\right)$ was put under permanent light. The long-day (LD) groups $\left(24 \mathrm{~L}_{1}, 16 \rightarrow 24 \mathrm{~L}_{1}\right.$, $16 \mathrm{~L}_{1}$ ) were pooled and 20 of the females were placed under natural conditions (group $\mathrm{LD}_{1}-\mathrm{C}_{2}$ ) and 20 under permanent light (group $\mathrm{LD}_{1}-24 \mathrm{~L}_{2}$ ) (Fig. 1). The fish were checked once every 2 months for ovulation.

Light, provided by a $100-\mathrm{W}$ incandescent bulb placed in the center of the tank cover, was measured at 1500 lux at the surface of the water and 160 lux at the bottom under the bulb. In the control groups, the tanks were covered as in the experimental group and light penetrated through a hole in the tank cover in the place of the bulb. Light intensity measured on sunny days was 2000 lux at the water surface and 120 at the bottom. During the summer the fish received pelleted food (Trouw; 7-mm size) for brood stock with added carotenoids during the spawning season (September-March). The average daily ration was $1 \%$ of body weight given twice on weekdays and once on Saturday and on Sunday. The fish were starved for 3 days before each handling and received a malachite green treatment once a week.

At the end of both reproductive seasons (1977/1978 and 1978/1979), the date of ovulation in females and the percentage of puberal fish were determined from bimonthly sampling starting on 15 November. The fecundity of the ovulated females was determined (number of ova collected) as well as the weight of 100 ova and the diameter of 30 . Fertility was evaluated in the $1977 / 1978$ season but not in the $1978 / 1979$ season due to the failure of the incubation system at the end of the experiment in March 


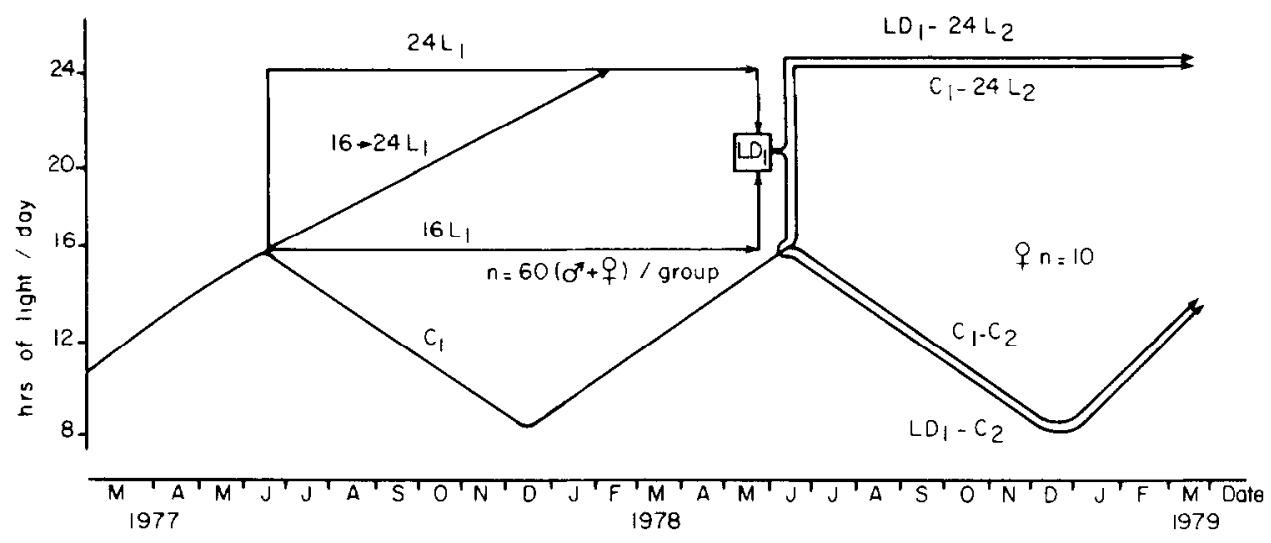

Fig. 1. Photoperiodic regime of trout: males and females during the first reproductive cycle $(1977 / 1978)$ and females during the second reproductive cycle (1978/1979). Four groups were first treated from 21 June 1977 to 21 June 1978: (1) $24 \mathrm{~L}$; continuous $24 \mathrm{~L}: 0 \mathrm{D} ;(2) 16 \rightarrow 24 \mathrm{~L} ; 16 \mathrm{~L}: 8 \mathrm{D}$ changing to $24 \mathrm{~L}: 0 \mathrm{D}$ in 7 months; (3) $16 \mathrm{~L}$; continuous 16L : $8 \mathrm{D} ;(4)$ control group $\mathrm{C}$; under described regime. The experimental design was reorganized on 21 June 1978 for the second reproductive season. All the experimental groups under long days (LD) were pooled, one part remained under continuous light $\left(\mathrm{LD}-24 \mathrm{~L}_{2}\right)$, the other was put under normal regime $\left(\mathrm{LD}-\mathrm{C}_{2}\right)$. Part of the control remained as a control $\left(C_{1}-C_{2}\right)$ and the others were put under permanent light $\left(C_{1}-24 L_{2}\right)$.

1979. The females were sacrificed and the GSI, VSI (viserosomatic index) and HSI (hepatosomatic index) were measured. These indexes were all calculated considering the weight of the carcass without viscera. The VSI included all the viscera but excluded the gonads.

In the males, the period of spermiation and the percentage of puberal fish were determined bimonthly. The volume of milt was measured and its fertilizing ability determined. The fertility test for males and females included artificial insemination according to Billard (1977) and incubation at $10^{\circ} \mathrm{C}$ for 20 days; the percentage of embryos was then calculated in relation to the percentage of fertilization. Fertility tests were carried out in duplicate on 14 December in all groups with pooled eggs from three to five recently ovulated females and the mixed milt of five males taken from each group; this allowed us to try to ascertain any interaction between gametes obtained from the different photoperiodic regimes.

Percentage values were compared by $\chi^{2}$ and other values by variance analysis (ANOVA).

\section{RESULTS}

The percentage of males out of the total population that spermiated during the first reproductive cycle is given in Fig. 2. When sampling started, group $\mathrm{C}_{1}$ males had already begun spermiation $(40 \%$ of the population were mature). Mean spermiation time was delayed by at least 1 month in the $16 \mathrm{~L}_{1}$ group and by about 2 months in the $16 \rightarrow 24 \mathrm{~L}_{1}$ and $24 \mathrm{~L}_{1}$ groups. 


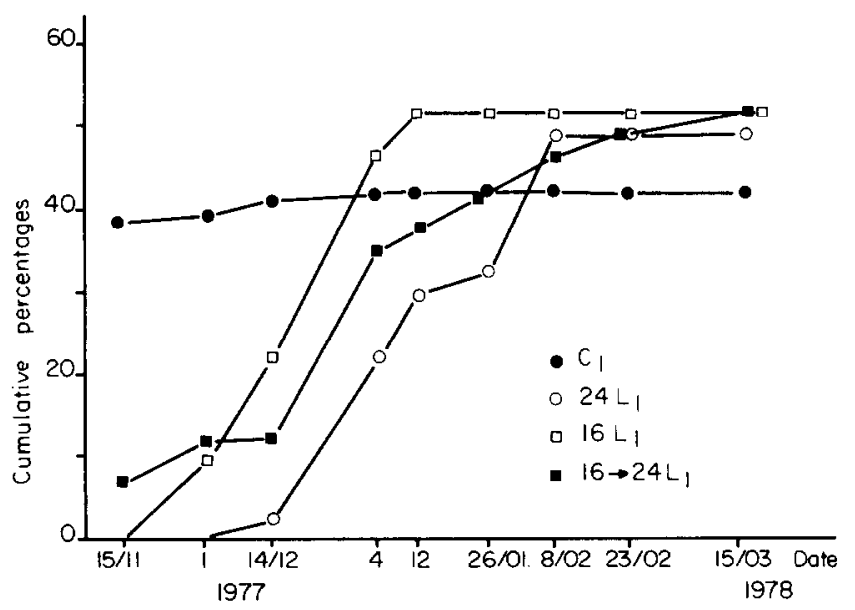

Fig. 2. Cumulative percentage of spermiating males in the total population during the $1977 / 1978$ reproductive season.

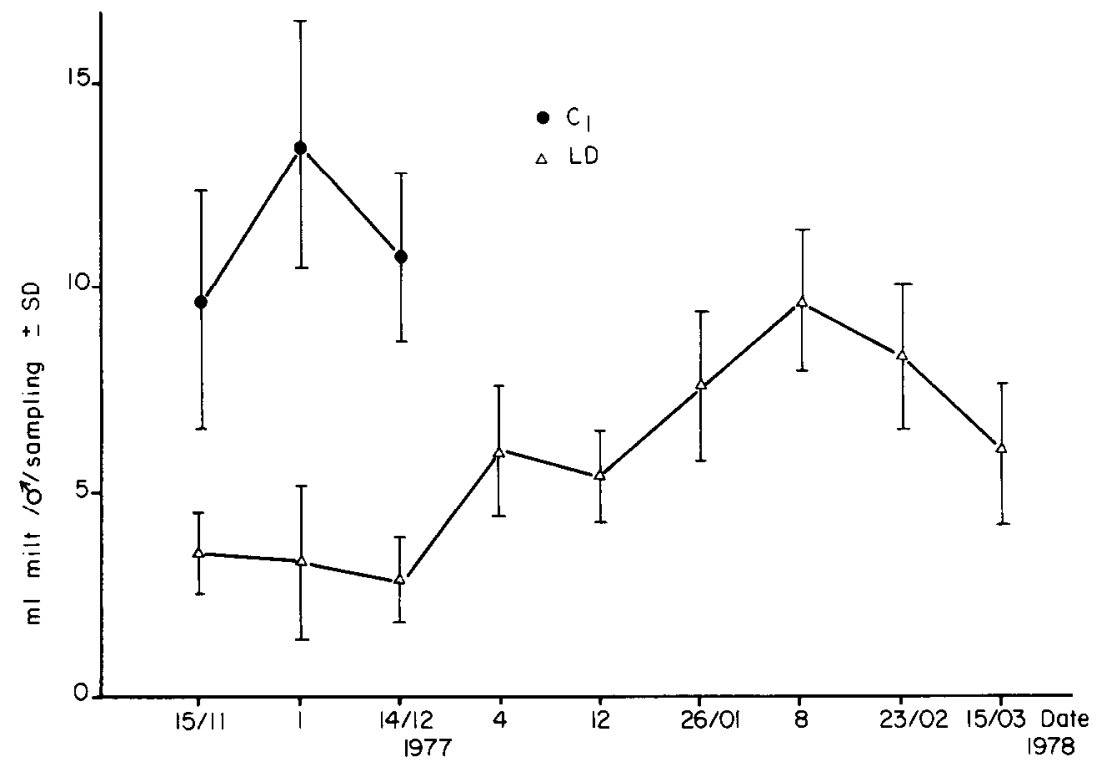

Fig. 3. Development of sperm production in group $C_{1}$ and pooled experimental LD groups. All fish in group $C_{1}$ died or were discarded because of a severe fungus infection.

The final percentage of puberal males was $10 \%$ higher in the experimental groups than in the control group but the differences were not significant $(P>0.05)$. The volume of sperm collected at each sampling is given in Fig. 3. All the males in group $\mathrm{C}_{1}$ died due to severe fungal growth after the third sampling. In all the experimental groups, the volume of milt collected was similar and the production of the three groups was pooled. Maximal 
production occurred in early February in the pooled long-day (LD) groups, i.e., 2 months later than the maximal production in the $C_{1}$ group. The pooled milt production of $\mathrm{C}_{1}$ (15 November-14 December) and LD (25 January -23 February) males were not significantly different $(P>0.05)$. The fertilizing ability of the sperm when tested with ova taken from $C_{1}$ control females was high and remained comparable to that of other groups (Table I).

Females in group $\mathbf{C}_{1}$ in their first reproductive cycle ovulated before 1 December (Fig. 4). In the other groups kept under longer photoperiodic regimes, the females ovulated slightly later and over a long period of time ( 3 months). In March the percentage of ovulated females was comparable

\section{TABLE I}

Percentage fertilization (eyed eggs) after insemination with milt and ova taken from the different groups: $\mathrm{C}_{1}, 16 \mathrm{~L} \rightarrow 24 \mathrm{~L}_{1}, 16 \mathrm{~L}_{1}, 24 \mathrm{~L}_{1} ; N=\delta: 5 ; q: 3-5$

\begin{tabular}{lllll}
\hline Males: & $\mathrm{C}_{1}$ & $16 \mathrm{~L} \rightarrow 24 \mathrm{~L}_{1}$ & $16 \mathrm{~L}_{1}$ & $24 \mathrm{~L}_{1}$ \\
\hline Females: & & & & \\
$\quad \mathrm{C}_{2}$ & $95 \pm 2$ & $97 \pm 1$ & $95 \pm 1$ & 92 \\
$16 \mathrm{~L} \rightarrow 24 \mathrm{~L}_{1}$ & $87 \pm 6$ & $90 \pm 6$ & $90 \pm 7$ & $93 \pm 5$ \\
$16 \mathrm{~L}_{1}$ & $93 \pm 6$ & $93 \pm 1$ & $91 \pm 2$ & 93 \\
\hline
\end{tabular}

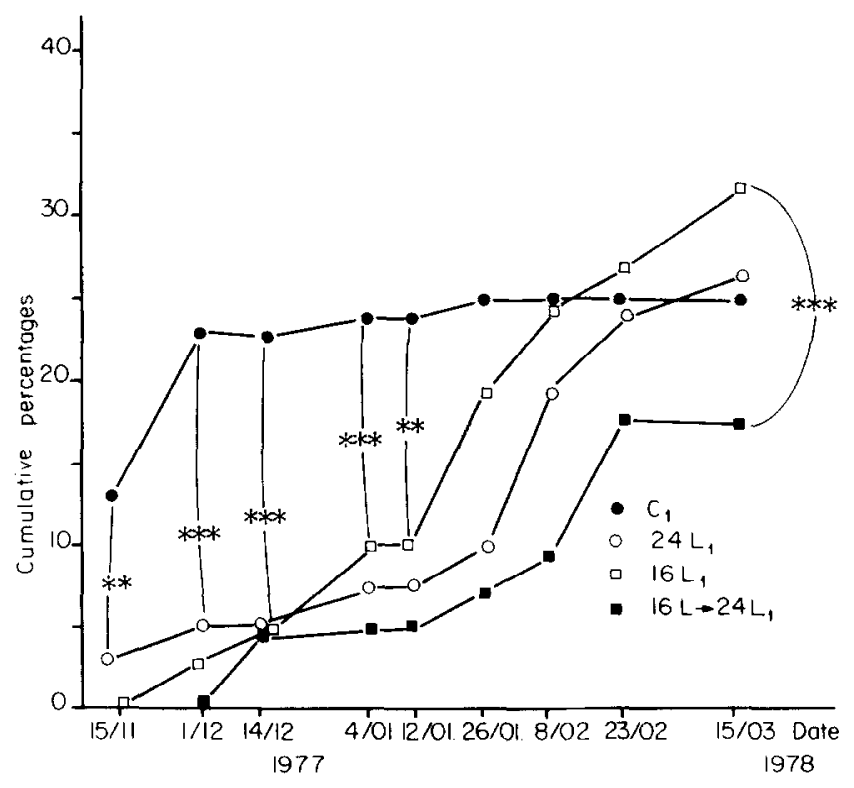

Fig. 4. Changes in the percentage of ovulated females in the mixed male and female population of each group during the first reproductive cycle. See Fig. 1 for group captions **: $P<0.01 ; * * *: P<0.001$. 


\section{TABLE II}

Somatic weight (excluding eggs) of the females, absolute fecundity (total number of ova/female) and relative fecundity (number of ova/kg somatic weight) and size and weight of the ova in the different groups; values are $\bar{x} \pm \mathrm{SD}$; results for the first reproductive cycle

\begin{tabular}{|c|c|c|c|c|c|}
\hline \multirow[t]{2}{*}{ Group } & \multirow{2}{*}{$\begin{array}{l}\text { Somatic } \\
\text { wt. (g) }\end{array}$} & \multicolumn{2}{|l|}{ Fecundity } & \multirow{2}{*}{$\begin{array}{l}\text { Ova } \\
\text { diameter } \\
(\mathrm{mm})\end{array}$} & \multirow{2}{*}{$\begin{array}{l}\text { Wt. of } \\
100 \text { ova } \\
\text { (g) }\end{array}$} \\
\hline & & Absolute & Relative & & \\
\hline $\mathrm{C}_{1}$ & $868 \pm 91.6$ & $1771 \pm 802$ & $2040 \pm 900$ & $4.96 \pm 0.60$ & $7.67 \pm 0.39$ \\
\hline $16 \mathrm{~L}_{1}$ & $893 \pm 127$ & $2065 \pm 1060$ & $2313 \pm 1200$ & $4.86 \pm 0.55$ & $7.54 \pm 0.34$ \\
\hline $24 L_{1}$ & $915 \pm 113$ & $2174 \pm 735$ & $2374 \pm 798$ & $4.82 \pm 0.47$ & $7.47 \pm 0.20$ \\
\hline $16 \mathrm{~L} \rightarrow 24 \mathrm{~L}_{1}$ & $888 \pm 127$ & $2098 \pm 455$ & $2361 \pm 515$ & $4.20 \pm 0.59$ & $6.55 \pm 0.37$ \\
\hline
\end{tabular}

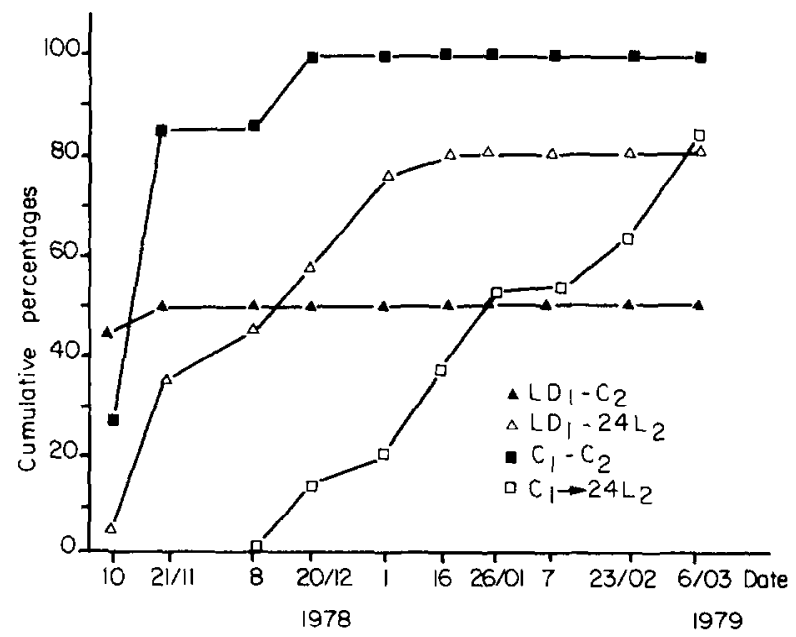

Fig. 5. Cumulative percentage of ovulation in female rainbow trout placed under various photoperiodic regimes during their second reproductive cycle.

in groups $\mathrm{C}_{1}, 24 \mathrm{~L}_{1}$ and $16 \mathrm{~L}_{1}$, but was significantly lower in group $16 \mathrm{~L} \rightarrow 24 \mathrm{~L}_{1}$ when compared to group $16 \mathrm{~L}_{1}$. There were no significant differences $(P>$ 0.05 ) between the groups for fecundity and size of ova (Table II).

During the second reproductive cycle, $50 \%$ of all the females ovulated on 10 November in the control group $C_{1}-C_{2}$ and in group $L D_{1}-C_{2}$ (Fig. 5). The mean ovulation time was delayed by 1 month in group $L D_{1}-24 L_{2}$ and by 2 months in group $\mathrm{C}_{1}-24 \mathrm{~L}_{2}$ with only $80 \%$ of the females having ovulated on 6 March; in group $\mathrm{LD}_{1}-\mathrm{C}_{2}$, only $50 \%$ of the females had ovulated. The non-ovulated females had oocytes in vitellogenesis when they were killed on 6 March (Table III). In all the groups previously kept under long days $\left(L D_{1}-C_{2}\right.$ and $\left.L D_{1}-24 L_{2}\right)$ the non-ovulated females showed abnormal ovaries with apparently normal oocytes of various sizes (between 2 and $5 \mathrm{~mm}$ ) and over-mature, swollen, non-ovulated and atretic follicles 
TABLE III

Body weight, GSI and average time of ovulation recorded in ovulated and non-ovulated females in various groups when killed at the end of the experiment; values are $\bar{x} \pm \mathrm{SD}$

\begin{tabular}{llrlll}
\hline Group & $\begin{array}{l}\text { State of } \\
\text { ovulation }\end{array}$ & $\begin{array}{l}N \\
\vee\end{array}$ & $\begin{array}{l}\text { Body } \\
\text { wt. (g) }\end{array}$ & GSI (\%) & $\begin{array}{l}\text { Period of } \\
\text { ovulation }\end{array}$ \\
\hline $\mathrm{C}_{1}-\mathrm{C}_{2}$ & Post-ovulated & 10 & $1415 \pm 173$ & $0.46 \pm 11$ & Dec. \\
$\mathrm{C}_{1} \cdots 24 \mathrm{~L}_{2}$ & Post-ovulated $^{\mathrm{a}}$ & 9 & $1453 \pm 150$ & $3.65 \pm 5.01$ & Mar. \\
& Non-ovulated $^{\mathrm{b}}$ & 2 & $1343 \pm 457$ & $5.66 \pm 4.73$ & \\
$\mathrm{LD}_{1}-\mathrm{C}_{2}$ & Post-ovulated & 6 & $1452 \pm 403$ & $0.51 \pm 0.52$ & Dec. \\
& Non-ovulated & 5 & $1424 \pm 284$ & $4.36 \pm 3.09$ & \\
$\mathrm{LD}_{1}-24 \mathrm{~L}_{2}$ & Post-ovulated & 10 & $1263 \pm 348$ & $0.24 \pm 0.09$ & Jan. \\
& Non-ovulated & 2 & $1573 \pm 470$ & $4.23 \pm 2.41$ & \\
\hline
\end{tabular}

a Four females in this group had partially ovulated.

${ }^{b}$ GSI and egg diameter were 2.32 and $2.5 \mathrm{~mm}$, respectively, in one female and 9.01 and $4.1 \mathrm{~mm}$ in the other.

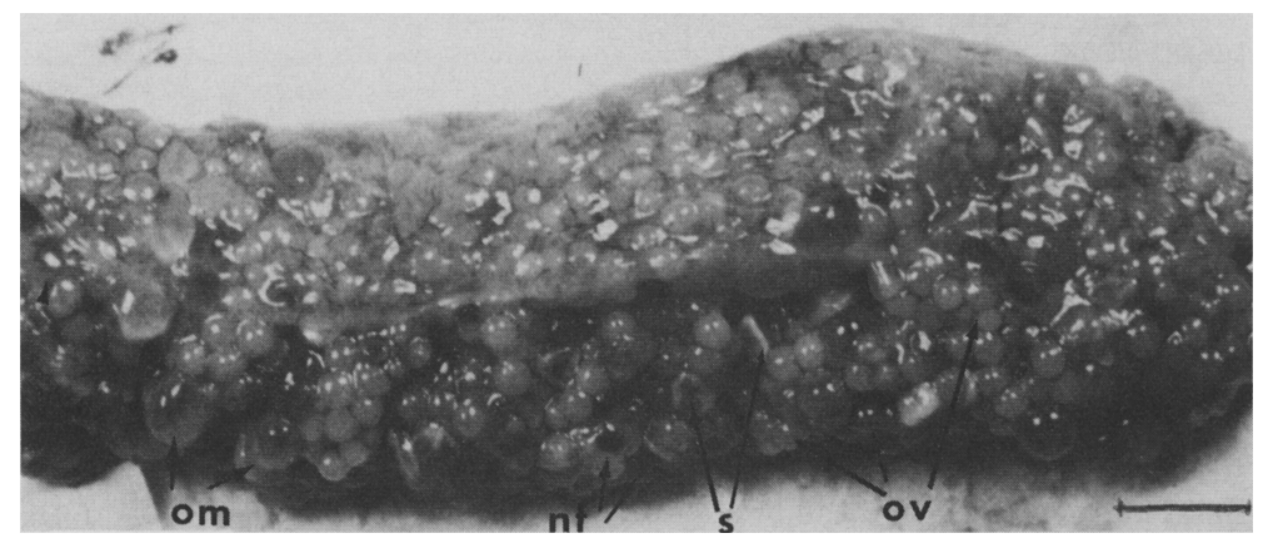

Fig. 6. Ovary of one of the non-ovulated females in group $L D_{1}-24 L_{2}$ killed in March 1979. A large variety of oocytes is seen. om: over-mature oocytes retained in the follicle; nf: necrotic follicle; s: egg shell in follicle; ov: oocytes of various sizes in vitellogenesis. The bar equals $1 \mathrm{~cm}$.

(Fig. 6). In these groups, we observed heterogeneity in the size class of small remnant oocytes in the ovulated females. In group $\mathrm{C}_{1}-24 \mathrm{~L}_{1}$ subjected for the first time to permanent light, four females showed only partial ovulation but they were in the process of ovulation and their ovaries appeared normal. The two non-ovulated females were still in the process of vitellogenesis or in a pre-ovulatory stage, as shown by the small size of the oocytes and the low plasma GTH level (data not shown). The reproductive performance of the ovulated females is shown in Table IV. 


\section{TABLE IV}

Reproductive performances recorded during the second year in females submitted to different photoperiodic regimes: somatic weight (excluding ovulated eggs), absolute fecundity (number of ova/female), relative fecundity (number of ova/kg somatic weight), weight of 100 ova and weight of ova in percent body weight (b.w.); values are $\bar{x} \pm S D$

\begin{tabular}{|c|c|c|c|c|c|c|}
\hline \multirow[t]{2}{*}{ Group } & \multirow{2}{*}{$\begin{array}{l}N \\
\subsetneq\end{array}$} & \multirow{2}{*}{$\begin{array}{l}\text { Somatic } \\
\text { wt. }^{\mathrm{a}} \\
\text { (g) }\end{array}$} & \multicolumn{2}{|l|}{ Fecundity } & \multirow{2}{*}{$\begin{array}{l}\text { Wt. of } \\
100 \text { ova } \\
\text { (g) }\end{array}$} & \multirow{2}{*}{$\begin{array}{l}\text { Ova } \\
\text { (\% b.w.) }\end{array}$} \\
\hline & & & Absolute & Relative & & \\
\hline $\mathrm{C}_{1}-\mathrm{C}$ & 10 & $1472 \pm 212$ & $3964 \pm 823$ & 2693 & $6.14 \pm 0.82$ & $16.6 \pm 2.8$ \\
\hline $\mathrm{C}_{1}-24 \mathrm{~L}_{2}$ & 9 & $1583 \pm 300$ & $4432 \pm 1128$ & 2800 & $4.64 \pm 0.88_{* *}^{* *}$ & $13.3 \pm 3.2$ \\
\hline $\mathrm{LD}_{1}-\mathrm{C}_{2}$ & 6 & $1573 \pm 401$ & $1878 \pm 887^{b}$ & 1194 & $6.37 \pm 0.89$ & $8.4 \pm 3.8$ \\
\hline $\mathrm{LD}_{1}-24 \mathrm{~L}_{2}$ & 10 & $1263 \pm 348$ & $2654 \pm 1354^{\mathrm{c}}$ & 2101 & $5.05 \pm 0.94$ & $12.2 \pm 7.1$ \\
\hline
\end{tabular}

${ }^{a}$ Recorded when ova were stripped.

${ }^{b}$ Significantly lower than the other groups $(P<0.005)$.

${ }^{c}$ Significantly lower than $\mathrm{C}_{1}-\mathrm{C}_{2}$ and $\mathrm{C}_{1}-24 \mathrm{~L}_{2}(P<0.0025)$.

$* P<0.025 ; * * P<0.01$.

\section{DISCUSSION}

Rainbow trout in their first reproductive cycle kept under a normal annual thermoperiodic regime and subjected after the summer solstice to long days (16L : $8 \mathrm{D}$; rising photoperiod: $16 \mathrm{~L}: 8 \mathrm{D}$ to $24 \mathrm{~L}$ : $0 \mathrm{D}$; or permanent light $24 \mathrm{~L}$ : $0 D$ ) showed a delay in spawning. The mid-period of spermiation and ovulation occurred about 1 month after the control group kept under normal photoperiod; ovulation and the onset of spermiation were spread over a period of 2-3 months, which was much longer than in the controls. This experiment confirms previous results by Bourlier and Billard (1984) on another strain which showed that constant light delays the spawning period and the process of gametogenesis in rainbow trout during the first reproductive cycle. In addition, the present experiment shows that long days also delay ovulation in fish in their second reproductive cycle (group $\mathrm{C}_{1}-24 \mathrm{~L}_{2}$ ). In this group, two females which had not ovulated at the end of the experiment showed normal looking pre-spawning ovaries although the GSIs were low; these fish probably would have ovulated later. During the first cycle, reproductive performance was not altered by the various photoperiodic regimes: in males milt production and sperm fertilizing ability remained similar; all females ovulated, eggs were large and highly fertile, and fecundity was not impaired by photoperiodic changes. Similar conclusions were reached in another strain of rainbow trout by Bourlier and Billard (1984): the spawning period was delayed and the quantity and quality of the sex products were not altered by long day or permanent illumination. However, these authors found a lower sperm production under long days. The ripening of the male Atlantic salmon was also delayed under long days (20L : 4D) (Lundqvist, 1980). 
The present experiment clearly shows that the second cycle was perturbed in fish kept under long days during the first reproductive cycle. Some females did not ovulate and showed oocyte retention, asynchronous follicle-oocyte development at various stages of vitellogenesis and fecundity that was significantly lower than the controls. This is probably due to long-day exposure during the first cycle since group $\mathrm{LD}_{1}-\mathrm{C}_{2}$ fish submitted first to long day and then to normal photoperiod also showed abnormalities: a very poor oogenetic yield, as shown by low fecundity in the ovulated females (Table IV) and a low GSI in the non-ovulated ones (Table III). Several hypotheses may be advanced to explain this delayed effect of exposure to long days. It may be that such egg retention (not reported before and not usually checked) was due to the heterogeneous nature of the group which had been pooled from the first year. It remains to be determined if a particular regime was more deleterious for the process of gametogenesis or ovulation. In trout ovaries at least two phenomenona occur simultaneously in the same year: (1) the process of vitellogenesis involving a batch of oocytes which will be ovulated that same year, and (2) the slow growth phase of the batch of oocytes entering into vitellogenesis the following year. Delaying vitellogenesis and ovulation with the associated morphological and endocrine changes implicated by long day may results in asynchrony in the two overlapping cycles, leading to perturbation in the one just beginning its final year. Another phenomenon linked to the previous one is dephasing between the annual changes in photoperiod and thermoperiod. Besides the fact that temperature and light may control different mechanisms at different times of the year, they are also putative entrainers of supposed endogenous rhythms occurring concurrently in trout. When they are dephased, the reproductive cycle may be perturbed. Such perturbations were observed by McQuarrie et al. (1978) who showed that abnormalities in the process of oogenesis and in ovum fertility occur in coho salmon submitted to advanced photoperiod and natural thermoperiod. When one potential entrainer is suppressed - as when the temperature remains constant during the cycle - successful gametogenesis has been reported (Breton and Billard, 1977; Bromage et al., 1982), although several successive cycles were not studied.

In the present experiment, one potential entrainer, temperature, was unchanged while the photoperiodic regime was strongly modified (increasing day, constant illumination) and changed from one year to another in one case so that the temporal shifting or alteration of the light regime and its phase change with temperature may have contributed to a disturbance of the various components of the gametogenesis cycle.

\section{ACKNOWLEDGEMENTS}

We wish to thank Drs. C. Weil, B. Breton and B. Chevassus for advice and helpful discussion, and Ms. A. Daifuku for editing the English text. 


\section{REFERENCES}

Allison, L.N., 1951. Delay of spawning in eastern brook trout by means of artificially prolonged light intervals. Prog. Fish Cult., 13: 111-116.

Billard, R., 1977. Utilisation d'un système TRIS-Glycocolle pour tamponner le dilueur d'insémination de truite. Bull. Fr. Piscic., 264: 110-112.

Bourlier, A. and Billard, R., 1984. Delay of gametogenesis and spawning by constant illuminating of rainbow trout (Salmo gairdneri) during the first reproductive cycle. Can. J. Zool., 62 : in press.

Breton, B. and Billard, R., 1977. Effects of light and temperature on the plasma gonadotropin and spermatogenesis in the rainbow trout (Salmo gairdneri). Ann. Biol. Anim., Biochim., Biophys., 17: 331-340.

Bromage, N., Whitehead, C., Elliott, J., Breton, B. and Matty, A., 1982. Investigations into the importance of daylength on the photoperiodic control of reproduction in the female rainbow trout. In: C.J.J. Richter and J.H.Th. Goos (Compilers), Reproductive Physiology of Fish. PUDOC, Wageningen, pp. 233-236.

Hazard, T.P. and Eddy, R.E., 1951. Modification of the sexual cycle in brook trout (Salvelinus fontinalis) by control of light. Trans. Am. Fish. Soc., 80: 158-162.

Henderson, N.E., 1963. Influence of light and temperature on the reproductive cycle of the Eastern brook trout, Salvelinus fontinalis M. J. Fish. Res. Board Can., 20: $859-897$.

Lundqvist, H., 1980. Influence of photoperiod on growth in Baltic salmon parr (Salmo salar L.) with special reference to the effect of precocious sexual maturation. Can. J. Zool., 58: 940-944.

MacQuarrie, D.W., Markert, J.R. and Vanstone, W.E., 1978. Photoperiod induced offseason spawning of coho salmon (Oncorhynchus kisutch). Ann. Biol. Anim., Biochim., Biophys., 18: 1051-1058.

Shiraishi, Y. and Fukuda, Y., 1966. The relation between the daylength and the maturation in four species of salmonid fish. Bull Freshwater Fish. Res. Lab. Tokyo, 16: $103-111$. 